\title{
Effects of the environment and culture depth on growth and mortality in juvenile Pacific oysters in the Strait of Georgia, British Columbia
}

\author{
David Cassis $^{1, *}{ }^{\text {, Christopher M. Pearce }}{ }^{2}$, Maria T. Maldonado ${ }^{1}$ \\ ${ }^{1}$ Ocean Biogeochemistry Lab, Department of Earth and Ocean Sciences, University of British Columbia, Vancouver, \\ British Columbia V6T 1Z4, Canada \\ ${ }^{2}$ Pacific Biological Station, Fisheries and Oceans Canada, Nanaimo, British Columbia V9T 6N7, Canada
}

\begin{abstract}
The effects of environmental variables, culture depth, and phytoplankton abundance and composition on juvenile Pacific oyster Crassostrea gigas growth and mortality were studied between June and October of 2008 at 4 sites in the Strait of Georgia, British Columbia, Canada. In addition, the effects of temperature-triggered depth manipulation on growth and mortality of oysters were examined in order to assess potential control measures for mitigating high summer mortalities associated with high temperature, harmful algal blooms (HABs), and other environmental stressors. Control oysters were held at constant depths of 3,10, and $15 \mathrm{~m}$, while experimental oysters were kept at $3 \mathrm{~m}$ depth and lowered to 10 or $15 \mathrm{~m}$ when the surface water temperature reached 14,16, or $18^{\circ} \mathrm{C}$. Site and Depth significantly affected the growth and mortality of control oysters. At the site with the best growth, cumulative mortality was low (range: 6.4 to $19 \%$ ) and negatively correlated with temperature and positively with transparency. At the high-mortality site (range: 64 to $98 \%$ ), mortality was positively correlated with temperature, chlorophyll concentration, and the biomass of diatoms and potentially harmful algae. Cumulative mortality was generally higher at $3 \mathrm{~m}$ than at $15 \mathrm{~m}$ depth. Significantly larger oyster volume was obtained with the oyster controls at $3 \mathrm{~m}$ than with those held at 10 or $15 \mathrm{~m}$ at most sites. Temperature-trigger treatments did not significantly affect oyster volume or cumulative mortality, and oysters moved to 10 and $15 \mathrm{~m}$ had final volumes similar to the 10 and $15 \mathrm{~m}$ controls, independent of trigger temperature. Oyster growers could select their sites for maximal growth and minimal mortality based on temperature profile, freshwater input, and phytoplankton abundance and composition.
\end{abstract}

KEY WORDS: Pacific oyster - Crassostrea gigas - Summer mortality - Harmful algae · HABs · Heterosigma akashiwo $\cdot$ Depth manipulation

\section{INTRODUCTION}

Globally, the Pacific oyster Crassostrea gigas Thunberg is the most common bivalve in aquaculture, owing to its handling ease, fast growth, euryhaline/ eurythermal tolerance, and the variety of culture techniques available (FAO 2006). In British Columbia (BC), Canada, the Pacific oyster is the largest cultured crop in terms of tonnage, the main areas of production being in the Strait of Georgia (Fig. 1) in Baynes Sound and Okeover Inlet. Nursery systems are often used for both wild-collected and hatchery-produced seed before grow-out. The oysters are then grown using a variety of methods, but generally suspended in the water column (Quayle 1988).

Pacific oysters grow rapidly during their first year and more slowly thereafter (Gangnery et al. 2003). Their growth rate is dependent on seawater temperature (reaching a metabolic optimum at $19^{\circ} \mathrm{C}$; Bougrier et al. 1995), food availability, and food quality (Brown \& Hartwick 1988a,b, Hyun et al. 2001, King et al. 2006). These variables can, in turn, be linked to culture depth 


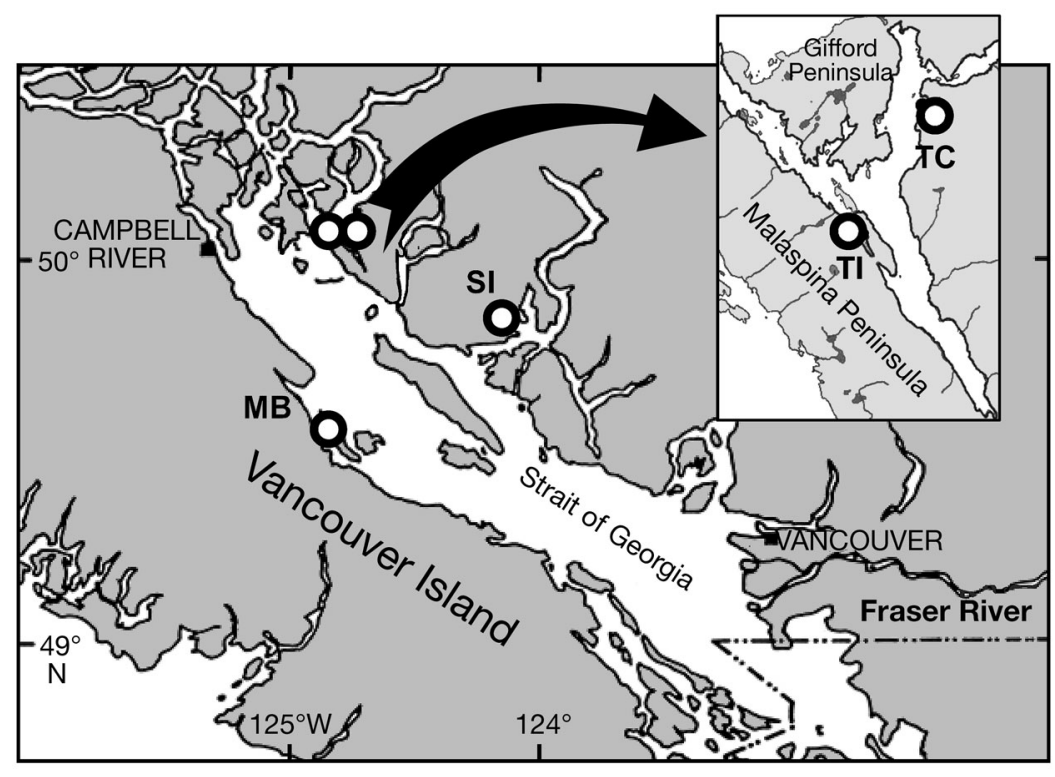

Fig. 1. Study site locations in the Strait of Georgia, British Columbia, Canada: Metcalf Bay (MB), Sykes Island (SI), Thor's Cove (TC), and Trevenen Inlet (TI)

during periods of low food availability, possibly causing an energetic deficit (Moal et al. 2007). Harmful algal blooms (HABs) can cause shellfish mortalities by means of oxygen depletion and/or toxin production (Shumway et al. 1990, Landsberg 2002). HABs can also reduce shellfish growth rates (Alexander et al. 2006) and filtration efficiencies (Gainey \& Shumway 1988, Cassis \& Taylor 2006), as well as damaging their digestive systems (Keppler et al. 2005, Galimany et al. 2008). Oysters may succumb to opportunistic viral and bacterial infections during or after periods of heightened environmental and/or physiological stress (Friedman et al. 1991, Cheney et al. 2000, Burge et al. 2007).

Growth and mortality of oysters have been investigated in large-scale (Brown \& Hartwick 1988a,b, Samain $\&$ McCombie 2007) and local (Toro et

(Ngo et al. 2006), water-column stratification, and nutrient abundance (Harrison \& Yin 1998).

Oysters are suspensivores that prefer seston rich in small diatoms and flagellates and poor in harmful algae and detritus (Baldwin \& Newell 1995, Chu et al. 2002). Oysters use their gills for particle selection, complemented by clapping of valves and other rejection reactions (Wildish et al. 1998, Cassis \& Taylor 2006). Pacific oysters develop particle-processing capabilities as they grow, reaching the adult level of selectivity at approximately $2.4 \mathrm{~cm}$ shell length (Cannuel \& Beninger 2007). This selectivity may have implications for their feeding capacity and the effects of blooms of harmful and noxious algae on growth and mortality (Cannuel \& Beninger 2007).

Mortalities of Pacific oysters during the summer months have been documented throughout the world and can affect between 10 and $50 \%$ of the juveniles (Samain \& McCombie 2007), with extreme cases involving $>90 \%$ mortality (Pauley et al. 1988, FAO 2006, Burge et al. 2007). Mortality rates are typically higher in smaller oysters than in larger ones and this may be associated with the physiological stress of fast growth (García-Esquivel et al. 2000). Larger oysters, however, can also suffer mortalities during the summer, mostly due to physiological stress and exertion during the reproductive period (Moal et al. 2007). Extreme mortality rates have been observed during periods of high seawater temperature, low salinity close to the surface, or phytoplankton blooms (Shumway et al. 1990, Cheney et al. 2000, Landsberg 2002). Temperatures above $19^{\circ} \mathrm{C}$ can stress oysters and increase their metabolism al. 1999, García-Esquivel et al. 2000, King et al. 2006) studies. Salinity was the determining factor for oyster growth in the Strait of Georgia (Brown \& Hartwick 1988a), while phytoplankton composition had a significant effect on oysters grown in Wales, UK (King et al. 2006). A number of studies (e.g. Sumner 1981, Gagnaire et al. 2006, King et al. 2006) have indicated that oysters typically grow faster closer to the surface, where food supply is abundant, although others have reported lower growth for oysters held close to the surface (Toro et al. 1999).

Salinity in the Strait of Georgia is typically around 32, but can reach values of 15 and lower in the vicinity of local sources of freshwater, producing a strong densitydriven stratification in the top 10 to $15 \mathrm{~m}$ of the water column (Thomson 1981). During the summer, the surface seawater temperature generally ranges between 15 and $24^{\circ} \mathrm{C}$ (Thomson 1981, Masson \& Cummins 2007), but summer temperature peaks of $25^{\circ} \mathrm{C}$ and greater can be observed close to the surface in some areas (Thomson 1981, this study). The water below the pycnocline generally maintains winter values of 6 to $8^{\circ} \mathrm{C}$ (Masson \& Cummins 2007). These temperature and salinity values are in the ranges considered acceptable for Pacific oysters (Pauley et al. 1988). Nonetheless, large oyster mortality events have been correlated with periods of extreme values and/or strong fluctuations of temperature (Cardwell et al. 1979, Pauley et al. 1988). The phytoplankton community in the Strait of Georgia follows typical annual cycles and successions of temperate estuaries: spring and fall blooms of diatoms and dominance of flagellates in sum- 
mer. The main species present are generally determined by the availability of nutrients and the watercolumn structure (Harrison \& Yin 1998).

Due to intense summer stratification, high temperature spikes and HABs in the Strait of Georgia normally occur in the upper $10 \mathrm{~m}$ of the water column (Taylor \& Harrison 2002), causing oyster mortalities and reducing oyster growth (Brown \& Hartwick 1988a,b). The objectives of the current study were to: (1) assess the effects of various environmental variables on oyster growth and mortality at $3 \mathrm{~m}$, the shallowest depth typically used by oyster growers in the Strait of Georgia; (2) determine the optimum depth for oyster culture $(3,10$, or $15 \mathrm{~m}$ ); and (3) establish if the manipulation of culture depth could be used to reduce exposure of oysters to damaging environmental conditions (e.g. high temperatures, large temperature fluctuations, HABs) and thus improve oyster growth and survival. Temperature, previously identified as one of the main variables involved in summer mortalities (Brown \& Hartwick 1988a,b, Burge et al. 2007), was selected as the trigger for depth manipulation in our experiment. A possible drawback of this approach is that moving oysters to deeper waters could result in lower food intake and reduced growth, since the abundance of beneficial phytoplankton is also highest near the water surface. We had 2 main hypotheses: (1) oyster growth rate would be highest at the shallowest depth tested $(3 \mathrm{~m})$ where temperatures and food levels would typically be greatest, and (2) oyster mortality rate would decrease with increasing depth (due to reduced spikes in high temperatures and concentration of harmful algae). The results of this research may allow oyster growers to reduce oyster mortalities and to optimize the distribution of their stock based on environmental monitoring.

\section{MATERIALS AND METHODS}

The depth-manipulation experiment was conducted from June to October 2008 at 4 commercial oyster farms within 3 of the main oyster-producing areas in the Strait of Georgia: Metcalf Bay (MB) in Baynes Sound; Sykes Island (SI) in Jervis Inlet; and Thor's Cove (TC) and Trevenen Inlet (TI) in Okeover Inlet (Fig. 1). At each of these sites, 27 oyster culture trays $(\mathrm{L} \times \mathrm{W} \times \mathrm{H}$ : $56.25 \times 56.25 \times 21.25 \mathrm{~cm}$ ) were stocked with hatchery-produced, diploid seed oysters. As no BC-wide industry standard exists, seed sizes and stocking densities particular to the companies that operate these commercial aquaculture leases were used for the experiment. Each individual tray at TC and TI was seeded with 1000 juvenile oysters (mean \pm SE shell height: $27.6 \pm 4.3 \mathrm{~mm}_{i} \mathrm{n}=10$ ), while each tray at MB and SI was stocked with $\sim 2500$ juvenile oysters (shell height: $5.3 \pm 0.4 \mathrm{~mm} ; \mathrm{n}=10$ ). Shell height was the longest distance from the umbo to the ventral margin of the shell. The seeded trays were distributed randomly on 2 rafts (MB, TC, and TI) or 2 sets of long lines (SI) at each site, again depending on company protocol. During the study, the experimental oysters were managed in the same manner as the other oysters at each site, which included thinning to avoid density-related growth problems. This was normally done by placing half of the oysters of the original tray into a new one, which was kept along with the old tray in the same tray stack. During sampling, both trays were counted and the data averaged across trays.

All treatments were conducted in triplicate, with 3 random trays being assigned to each treatment; 3 sets of triplicate trays were kept at fixed depths $(3,10$, and $15 \mathrm{~m}$ ) throughout the experiment, while the rest of the trays were divided into 3 sets of 6 trays each and assigned a trigger temperature $\left(14,16\right.$, or $\left.18^{\circ} \mathrm{C}\right)$ (Fig. 2). The 6 trays assigned to each temperature trigger were divided into 2 groups, one to be lowered to $10 \mathrm{~m}$ and the other to $15 \mathrm{~m}$. The temperature-triggered trays were kept at $3 \mathrm{~m}$ depth until the seawater temperature at $3 \mathrm{~m}$ reached their temperature trigger. Once each particular temperature trigger was reached, the trays of oysters were lowered to their predetermined depths (10 and $15 \mathrm{~m})$. These lowered trays were then brought

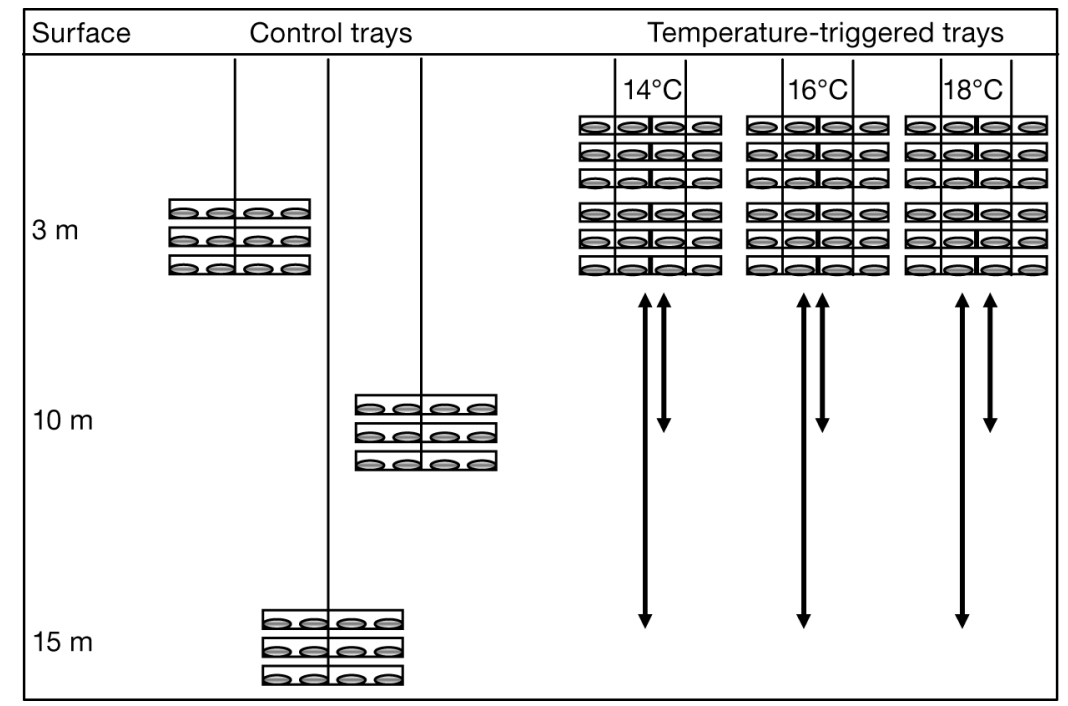

Fig. 2. Experimental design for depth manipulation trial. Control trays $(\mathrm{n}=3)$ were kept at 3,10 , and $15 \mathrm{~m}$ depth throughout the study, whereas the temperature-triggered trays $(n=3$ per trigger temperature and target depth) were held at $3 \mathrm{~m}$ and dropped to either 10 or $15 \mathrm{~m}$ when the seawater at $3 \mathrm{~m}$ reached the trigger temperature 
back to $3 \mathrm{~m}$ depth when the seawater temperature at $3 \mathrm{~m}$ dropped below the temperature trigger. The depths chosen represented the upper depth normally used by oyster farmers $(3 \mathrm{~m})$, the depth of the pycnocline, which was also the lower depth typically used by the growers $(10 \mathrm{~m})$, and the deeper and colder water layer below the pycnocline $(15 \mathrm{~m})$.

Every $2 \mathrm{wk}$, the experimental and control trays were lifted out of the water and the shell heights of 5 randomly chosen oysters from each tray were measured with digital callipers. Oyster volume was estimated by measuring the water volume displaced by a random sample of oysters from each replicate tray. The sample sizes used during this experiment ( $>60$ oysters per tray at $\mathrm{MB}$ and $\mathrm{SI}$ and $>20$ oysters per tray at TC and TI) are similar to other oyster growth studies (Toro et al. 1999, King et al. 2006) and were the highest number possible under the commercial farm conditions. Instant growth and mortality rates were calculated using the difference between one sample and the next, divided by the number of days between measurements. Oyster mortality was only determined at MB and SI during the volume measurements, as the sample size used for volume estimation at TC and TI was too small to accurately gauge mortalities.

Temperature was monitored daily at $3 \mathrm{~m}$ with a Clinefinder digital probe (Catalina Technologies). Temperature at 3,10 , and $15 \mathrm{~m}$ depth was recorded at each site every $3 \mathrm{~h}$ for the duration of the experiment by duplicate automatic data loggers (Tidbit V.2, Onset). Water samples were obtained every $2 \mathrm{wk}$ at 3, 10, and $15 \mathrm{~m}$ for salinity measurement (STX-3 refractometer, Vee Gee Scientific) and quantitative evaluation of phytoplankton abundance. Secchi depth measurements and vertical tows of a plankton net (20 $\mathrm{mm}$ mesh) from $15 \mathrm{~m}$ depth were also conducted every $2 \mathrm{wk}$ at each site. Seawater density was calculated using UNESCO's Equation of State for Seawater (Gill 1982). The stratification intensity of the water column was defined as the difference in density between 3 and $15 \mathrm{~m}$.

Water mounts were analyzed quantitatively for microphytoplankton and small zooplankton by the Utermöhl method with modifications described in Hasle (1978). Gently homogenized water samples were placed in 5,10 , or $25 \mathrm{ml}$ settling chambers for 24 to $48 \mathrm{~h}$. The detailed composition of these samples was obtained under an Axiovert 10 inverted microscope (Carl Zeiss). Once the phytoplankton were counted and identified, the biovolumes were estimated using previously determined bio-volumes of local species (Haigh et al. 1992). These estimates were then used to calculate phytoplankton carbon biomass using equations from Strathmann (1967) and Montagnes \& Franklin (2001). The phytoplankton counts were converted to carbon biomass to avoid problems associated with quantitative phyto- plankton estimates based solely on cell counts. Usually phytoplankton cell counts, without estimates of carbon or bio-volume, overestimate the importance of small species that are present in large numbers and underestimate large species at low abundances. Chlorophyll samples were taken monthly from 3,10, and $15 \mathrm{~m}$ depth. Seawater samples $(250 \mathrm{ml})$ were $\mathrm{GF} / \mathrm{F}$ filtered $(0.7 \mu \mathrm{m})$, and the filters were frozen at $-20^{\circ} \mathrm{C}$ until analysis by chlorophyll extraction in $90 \%$ acetone and fluorescence measurement in a 10AU fluorometer (Turner Designs).

We conducted 2- and 3-way ANOVAs on oyster volume and mortality per pair of sites that shared the same initial seed size (i.e. MB and SI, and TC and TI). Tukey's multiple comparison post hoc tests were used to determine significant $(\mathrm{p}<0.05)$ differences among 3 or more treatment means. Prior to the ANOVAs, the data sets were tested for normality using the Kolmogorov-Smirnov test and for homoscedasticity using Bartlett's test. All data sets were normally distributed and homogeneous. Two-tailed Dunnett's tests were used to compare the 6 experimental treatments against the $10 \mathrm{~m}$ control within sites (comparisons with $15 \mathrm{~m}$ controls were also tried, with similar results). Correlations between environmental variables and instant oyster mortality and growth were examined using Pearson correlation coefficients with $\alpha<0.05$. The statistical analyses were performed with XLStat for Windows (Addinsoft). The data analysis was tried with several different time lags, but the best results and most significant correlations were obtained with data of the same time period (i.e. no lag).

\section{RESULTS}

\section{Environmental variables}

Seawater temperature varied between $26.2^{\circ} \mathrm{C}$ during August at SI at $3 \mathrm{~m}$, and $6.0^{\circ} \mathrm{C}$ in October at TC at $15 \mathrm{~m}$. The average temperature was highest at SI $\left(\right.$ mean $\left.\pm \mathrm{SE}: 16.3 \pm 2.2^{\circ} \mathrm{C}\right)$ and lowest at $\mathrm{MB}(14.9 \pm$ $\left.2.2^{\circ} \mathrm{C}\right)$, whereas TC $\left(15.2 \pm 1.8^{\circ} \mathrm{C}\right)$ and $\mathrm{TI}\left(15.3 \pm 2.0^{\circ} \mathrm{C}\right)$ were intermediate and shared a very similar temperature regime. Several short periods of increased temperature throughout the water column were detected at all sites, with the longest periods occurring during July and August (Fig. 3). Seawater temperature rapidly decreased in September and October. In terms of the percentage of days on which the temperature at $3 \mathrm{~m}$ depth was above the trigger temperature, oysters in the $14^{\circ} \mathrm{C}$ group remained dropped to lower depths for the longest time at $\mathrm{SI}$ and for the shortest time at $\mathrm{MB}$ (Table 1). The oysters in the 16 and $18^{\circ} \mathrm{C}$ treatments spent the least amount of time at lower depths at TC and the most at SI (Table 1). 


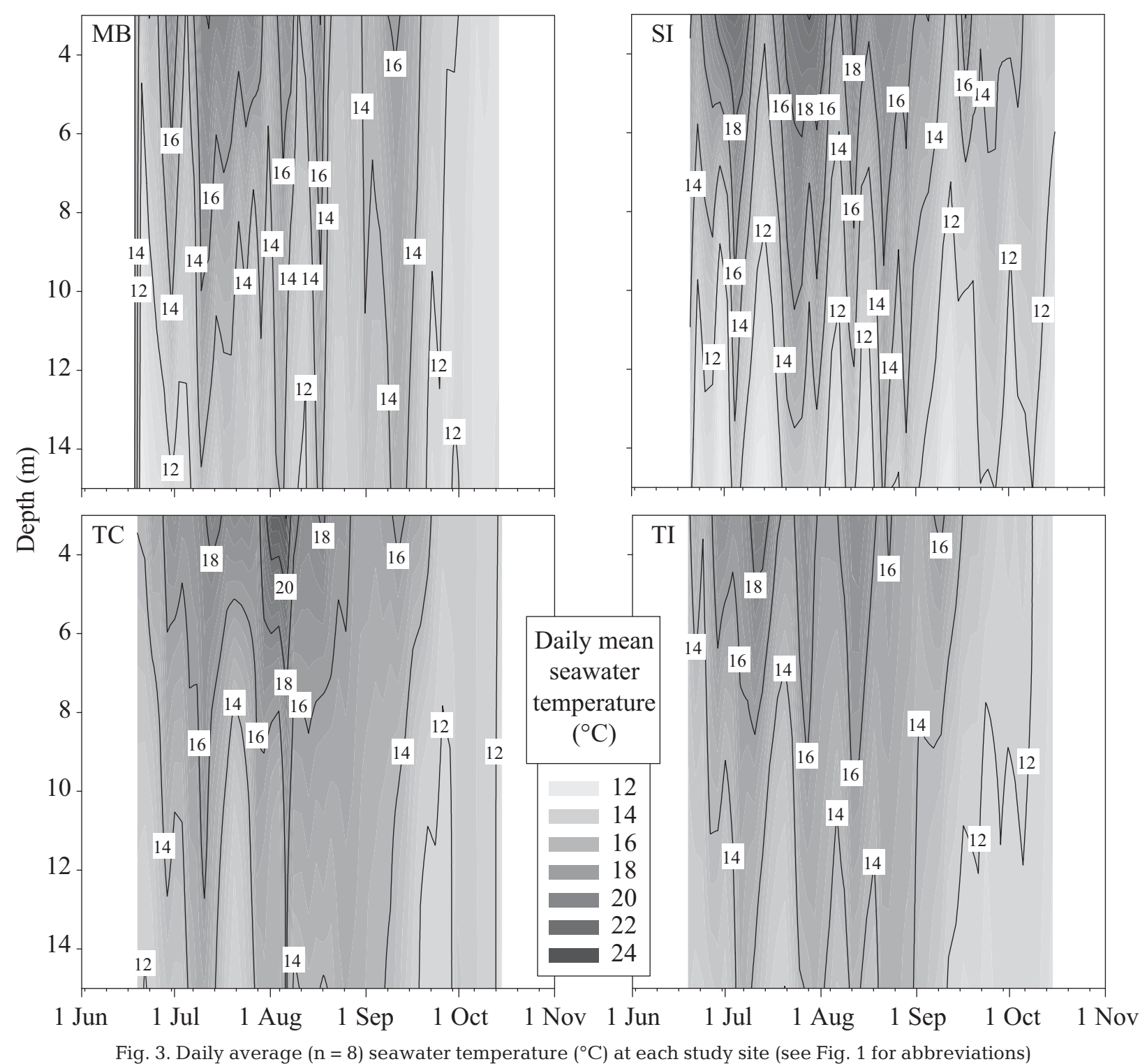

Salinity varied from 19 at SI during early July, to 30 in October at MB. Low values of salinity, 20 to 24, were observed close to the surface at most sites during June and July (Fig. 4). Higher salinities were common at greater depth and throughout the water column from August onwards. Among all sites, SI presented the lowest values of salinity and for the longest period. Salinity-driven stratification was high at all sites during June and July, and especially strong at SI, which continued with high to moderate stratification until the fall (Fig. 4).

Chlorophyll concentrations ranged from $15.92 \mathrm{mg} \mathrm{m}^{-3}$ ( $3 \mathrm{~m}$ in June at TI) to $0.34 \mathrm{mg} \mathrm{m}^{-3}$ (15 $\mathrm{m}$ in July at TC). A 3-way ANOVA indicated that Site $(F=5.41, \mathrm{df}=3,24$, $\mathrm{p}=0.005)$, Depth $(F=14.63, \mathrm{df}=2,24, \mathrm{p}<0.0001)$, and Date $(F=7.04, \mathrm{df}=4,24, \mathrm{p}=0.001)$ all had significant effects on chlorophyll concentration. The TC site had the lowest chlorophyll values, while TI and SI had relatively high chlorophyll peaks during June and August (Table 2). The chlorophyll values observed at MB were intermediate. During the summer months, the average chlorophyll concentrations were normally higher at 3 and $10 \mathrm{~m}$ depth than at $15 \mathrm{~m}$ at all sites, with a large

Table 1. Percentage of days with water temperatures at $3 \mathrm{~m}$ depth above the trigger temperatures at each study site (see Fig. 1 for abbreviations)

\begin{tabular}{|c|c|c|c|}
\hline \multirow[t]{2}{*}{ Site } & \multicolumn{3}{|c|}{ Trigqer temperature $\left({ }^{\circ} \mathrm{C}\right)$} \\
\hline & 14 & 16 & 18 \\
\hline MB & 64.5 & 37.0 & 11.0 \\
\hline SI & 86.9 & 54.4 & 25.0 \\
\hline TC & 79.7 & 31.7 & 9.5 \\
\hline TI & 73.2 & 43.3 & 10.2 \\
\hline
\end{tabular}




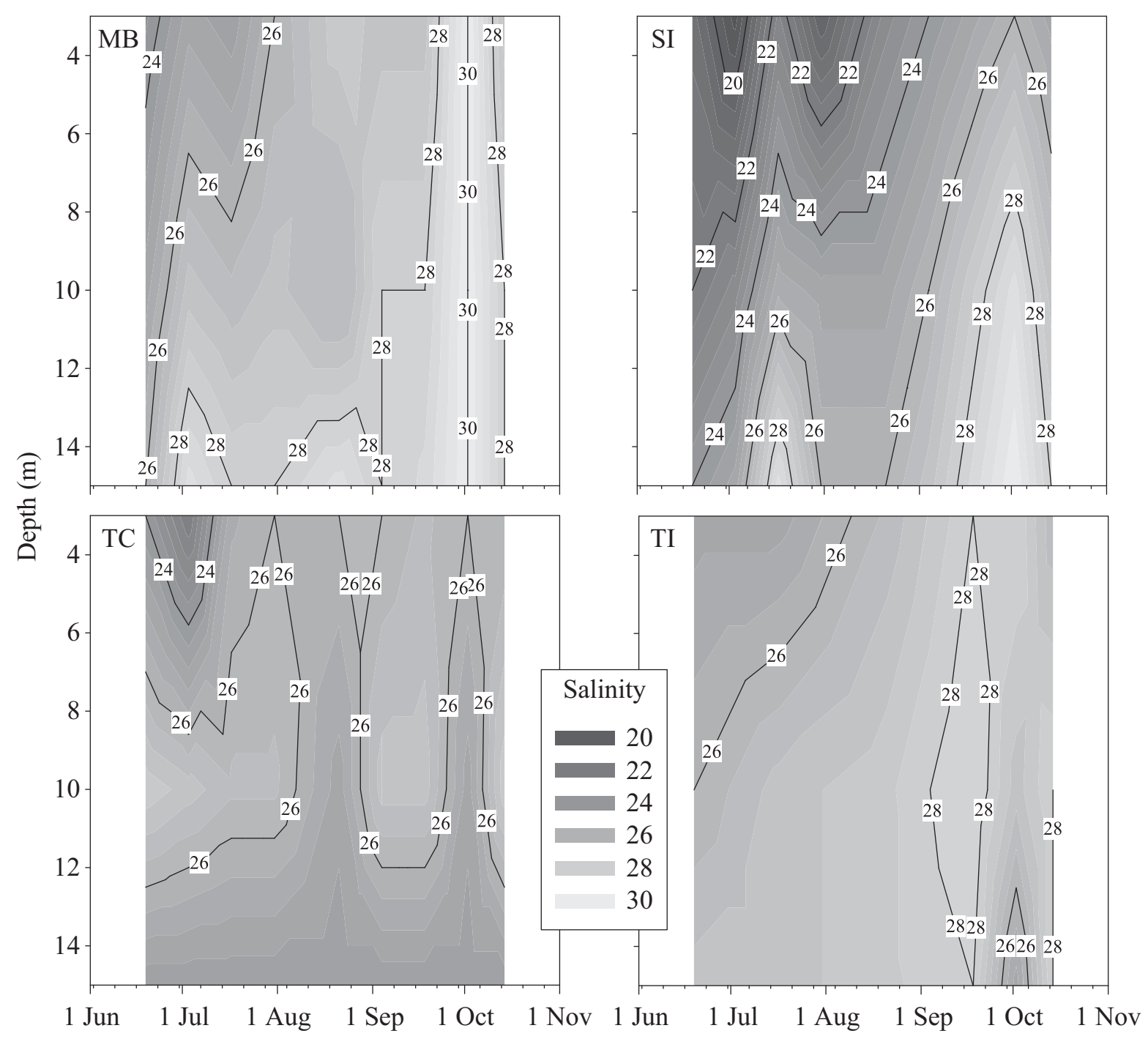

Fig. 4. Salinity at each study site, sampled every 2 wk $(n=1)$ (see Fig. 1 for abbreviations)

variation among months. The average difference between values at 3 and $15 \mathrm{~m}$ was lowest at MB with 2.7 times more chlorophyll at the surface than at $15 \mathrm{~m}$ depth. TC had the largest average depth difference in chlorophyll with around 7.1 times higher values at the surface than at $15 \mathrm{~m}$, while SI and TI averaged 4.2 and 5.3 times more chlorophyll, respectively, at the shallowest depth than at $15 \mathrm{~m}$.

The total phytoplankton biomass varied widely throughout the experimental period and among sites, generally being concentrated towards the surface with much lower values at depth (Fig. 5). This pattern was broken several times by blooms of different species during the summer and by the fall bloom of diatoms. The fall bloom was barely noticeable in the biomass profiles at most sites, but it was easily recognizable due to a sudden increase in the population of Skeletonema costatum (Greville) Cleve. The phytoplankton community at $\mathrm{MB}$ had a high abundance of mainly diatoms (mean of $95 \%$ of total carbon biomass across all sample dates) at all depths and months except for August. TI and TC had similar average proportions for various phytoplankton types with dinoflagellates comprising about $45 \%$ of the biomass, while equal proportions of diatoms and other phytoplankton species accounted for the remaining $55 \%$. SI was the site with the lowest overall diatom abundance $(6 \%)$, with dinoflagellates and other phytoplankton species dominating.

HABs, which were detected at all sites, were divided into 2 groups: (1) species potentially harmful to shellfish (potentially harmful algal blooms or pHABs) due to spiny projections, associated harmful bacteria, and/or the production of irritants or other harmful chemicals (i.e. Heterosigma akashiwo (Y. Hada) Y. Hada ex Y. Hara \& M. Chihara), Dictyocha speculum Ehrenberg, Ceratium fusus (Ehrenberg) Dujardin, Protoceratium 
Table 2. Monthly $(\mathrm{n}=1)$ chlorophyll concentrations $\left(\mathrm{mg} \mathrm{m}^{-3}\right)$ (see Fig. 1 for abbreviations)

\begin{tabular}{|lccccr|}
\hline Month & Depth $(\mathrm{m})$ & MB & SI & TC & TI \\
\hline June & 3 & 1.82 & 5.29 & 4.25 & 15.92 \\
& 10 & 1.26 & 6.40 & 0.92 & 2.07 \\
July & 15 & 0.78 & 1.78 & 0.44 & 1.02 \\
& 3 & 3.95 & 1.82 & 3.14 & 6.48 \\
& 10 & 1.56 & 2.29 & 0.61 & 1.79 \\
August & 15 & 0.65 & 0.67 & 0.34 & 1.05 \\
& 3 & 3.12 & 13.08 & 4.28 & 13.30 \\
September & 10 & 3.31 & 12.72 & 0.71 & 9.77 \\
& 15 & 1.42 & 1.79 & 0.41 & 4.29 \\
October & 10 & 5.20 & 7.25 & 3.22 & 1.96 \\
& 15 & 5.28 & 3.74 & 0.75 & 1.77 \\
& 3 & 3.45 & 0.94 & 0.71 & 2.01 \\
& 10 & 3.20 & 0.73 & 0.84 & 0.63 \\
& 15 & 2.55 & 1.32 & 0.49 & 0.98 \\
\hline
\end{tabular}

reticulatum (Claparède et Lachmann) Bütschli, and Rhizosolenia setigera Brightwell), and (2) species that potentially cause toxicity in shellfish (toxic HABs or tHABs) (i.e. Alexandrium spp. Halim, Dinophysis spp. Ehrenberg, and Pseudo-nitzschia spp. H. Peragallo in H. \& M. Peragallo). Most HABs were produced by pHABs, with tHABs only appearing in medium to low abundances and mostly during short periods of time.

Potentially harmful algae comprised 16 to $34 \%$ of the total phytoplankton biomass per site across all sample dates, with the highest proportion occurring at SI and TI ( $34 \%$ at both sites) and the lowest occurring at TC and MB (16 and 20\%, respectively). Throughout the sites studied, pHABs were normally more abundant towards the surface, with some blooms affecting the whole water column (Fig. 6). The intensity of the blooms was highest at SI, where up to $93 \%$ of the total phytoplankton biomass was made up of pHABs during 2 large blooms in June and August (Fig. 6). TC and TI had a small bloom in June and a large one during August and September. Potentially harmful algae were scarce at MB where only 2 short blooms were observed (Fig. 6), reaching a maximum of $40 \%$ of the total phytoplankton biomass. Although pHABs were present at all sites, SI and TI were the most affected by blooms of Heterosigma akashiwo, Dictyocha speculum, and Protoceratium reticulatum during June, and Ceratium fusus and P. reticulatum during August and September. Rhizosolenia setigera was only present at MB in low abundances during October.

Normally, tHABs reached only marginal levels of biomass, being scarce in SI while constantly present at low levels in MB. At the latter site, Pseudo-nitzschia spp. were common with sporadic appearances by Alexandrium spp. and Dinophysis spp. TC and TI had the highest relative abundance of toxic algae of all sites, as Alexandrium spp. were observed throughout
July and August while Pseudo-nitzschia spp. were detected during the fall bloom.

\section{Depth-manipulation experiment}

At all sites and in all treatments, Oyster volume and Shell height were closely correlated in an allometric relationship described by the formula: Volume = $(0.0004 \times \text { Shell height })^{2.7234}\left(R^{2}=0.9757, p>0.0001\right)$. Given that the initial oyster seed size was substantially different between the 2 companies participating in this study (i.e. shell height of $5.3 \pm 0.04 \mathrm{~mm}$ at $\mathrm{MB}$ and SI, and $27.6 \pm 4.3 \mathrm{~mm}$ at $\mathrm{TC}$ and $\mathrm{TI}$ ), the results of the experiment are divided by sites that shared the same initial seed size (i.e. MB and SI, and TC and TI).

Correlations of instant growth and mortality with environmental variables

Instantaneous growth rate of the oysters at $3 \mathrm{~m}$ depth at the various sites was positively correlated only with different components of the phytoplankton community: diatoms (\% of total phytoplankton biomass) at SI, dinoflagellates (\% of total phytoplankton biomass) at $\mathrm{MB}$, dinoflagellates (biomass) at TC, and pHABs (biomass) at TI (Table 3). Growth rate was negatively correlated with Date at TC. Instantaneous oyster growth was not significantly correlated with Temperature, Salinity, Secchi depth, or Chlorophyll concentration at any of the 4 sites (Table 3 ).

Instantaneous oyster mortality rate at SI was strongly positively correlated with Temperature, Diatom biomass, pHAB biomass, and Chlorophyll concentration (Table 4). The much lower mortality rate registered at $\mathrm{MB}$ was positively correlated with Secchi depth and negatively correlated with Temperature (Table 4). Instantaneous mortality rates at TC and TI were very low and random, not being associated with any specific environmental variable (data not shown). The cumulative mortality rates observed at TC and TI were 3 and $7 \%$, respectively.

Final oyster volume at MB and SI

A 2-way ANOVA on the 3,10, and $15 \mathrm{~m}$ controls indicated that the final volume of control oysters at the fixed depths was significantly affected by both Site and Depth, with no significant interaction between the 2 factors (Table 5). Oysters were significantly larger at MB than at SI and significantly larger when held at $3 \mathrm{~m}$ than when held at 10 or $15 \mathrm{~m}$, with no significant difference between oyster size at 10 and $15 \mathrm{~m}$ (Fig. 7A). 


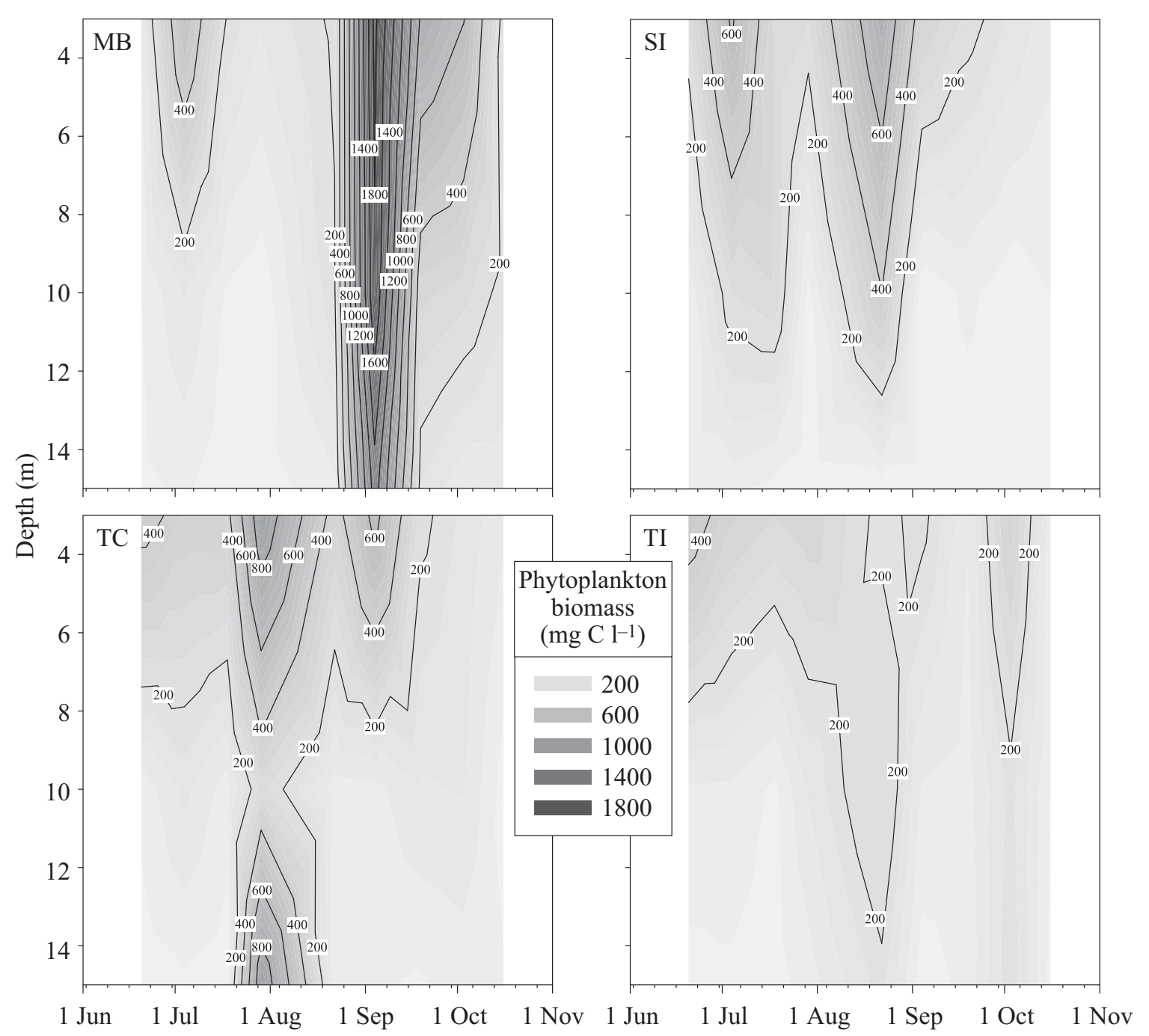

Fig. 5. Total phytoplankton biomass $\left(\mathrm{mg} \mathrm{C} \mathrm{l}^{-1}\right)$ at each study site, sampled every $2 \mathrm{wk}(\mathrm{n}=1)$ (see Fig. 1 for abbreviations)

A 3-way ANOVA on the temperature-triggered treatments indicated that the final volume of experimental oysters at MB and SI was only affected by Site with no other significant main effects or interactions (Table 6). The depth-manipulated oysters at MB were significantly larger at the end of the experiment than those at SI (Fig. 7A). No significant differences (using Dunnett's 2-tailed tests) were observed between the 10 or $15 \mathrm{~m}$ temperature-triggered treatment groups and the respective $10 \mathrm{~m}$ control groups at either site (Fig. 7A).

Final oyster volume at TC and TI

A 2-way ANOVA on the 3,10, and $15 \mathrm{~m}$ controls indicated that only Depth significantly affected the final volume of control oysters at these 2 sites, with no signif- icant effect of Site or the Site $\times$ Depth interaction (Table 5). Oysters held at $3 \mathrm{~m}$ were significantly larger than those held at 10 or $15 \mathrm{~m}$, but there was no significant difference in oyster volume between 10 and $15 \mathrm{~m}$ depth (Fig. 7B).

A 3-way ANOVA on the temperature-triggered treatments indicated that the final volume of experimental oysters at TC and TI was affected by Site and Test depth with no other significant main effects or interactions (Table 6). The depth-manipulated oysters at TC were significantly larger at the end of the experiment than those at TI, and oysters that were dropped to $10 \mathrm{~m}$ were significantly larger than those moved to $15 \mathrm{~m}$ (Fig. 7B). Comparisons between the temperature-triggered treatments and the $10 \mathrm{~m}$ control using Dunnett's 2-tailed test indicated no significant differences at either site (Fig. 7B). Oysters in the $15 \mathrm{~m}$ TC control group had the lowest final volume of all treatments. 


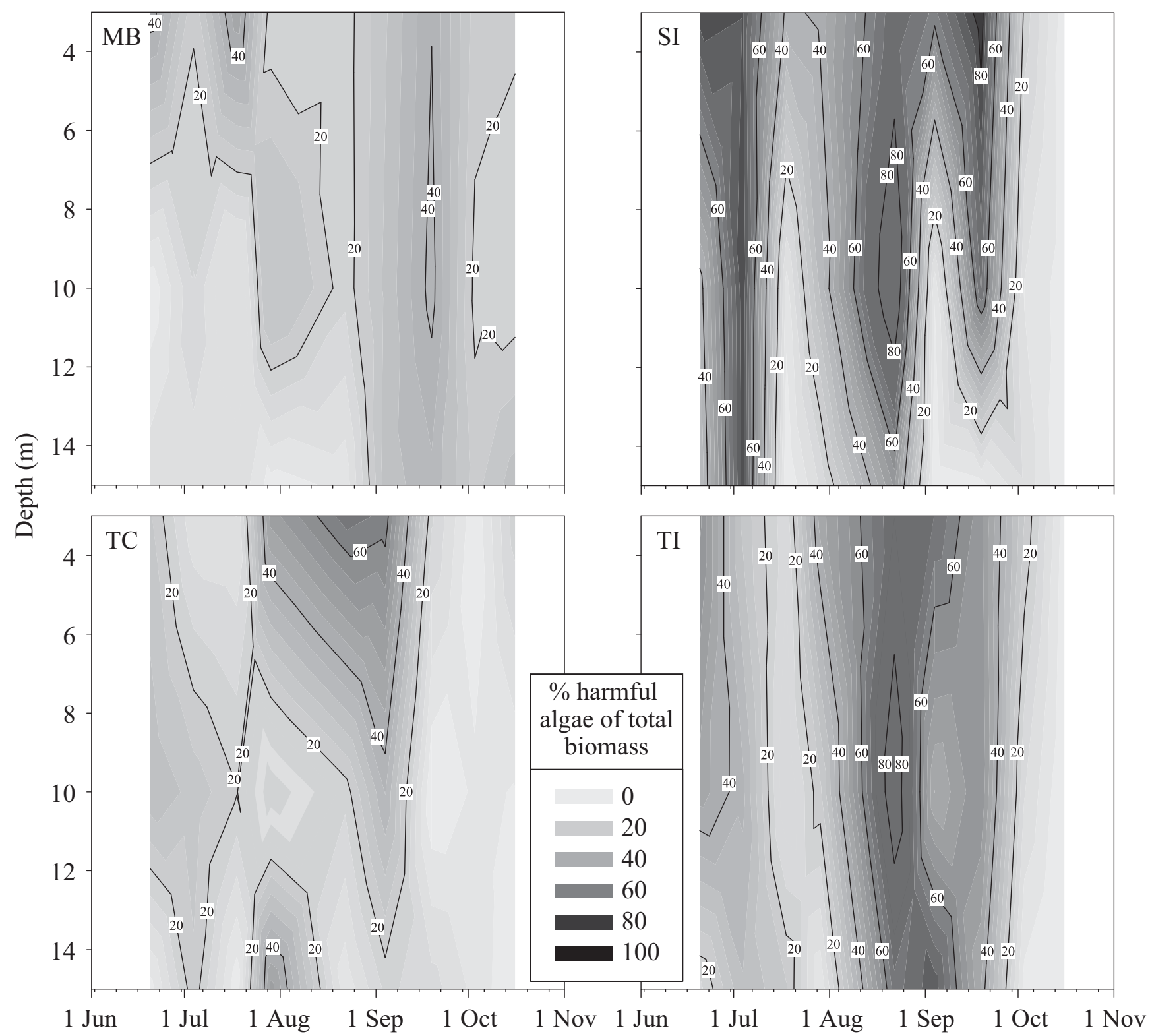

Fig. 6. Percentage of potentially harmful algae of the total phytoplankton biomass (\%) at each study site, sampled every 2 wk $(\mathrm{n}=1)$ (see Fig. 1 for abbreviations)

Oyster mortality at MB and SI

A 2-way ANOVA on the cumulative mortality of the fixed-depth controls at 3,10, and $15 \mathrm{~m}$ at MB and SI indicated that Site and Depth significantly affected oyster mortality, whereas the interaction between the factors was not significant (Table 5). SI had significantly higher cumulative oyster mortality than MB (Fig. 8). Despite the significant Depth effect in the ANOVA, a Tukey's test on data combined across the 2 sites did not indicate any significant pair-wise comparisons among depths. The Site $\times$ Depth interaction term was non-significant $(p=0.081)$, but it may be more appropriate to examine the effect of Depth within sites instead. At SI there was significantly higher cumulative mortality at $3 \mathrm{~m}$ than at 10 or $15 \mathrm{~m}$, while there were no significant pair-wise comparisons among depths at $\mathrm{MB}$ (Fig. 8).

A 3-way ANOVA on the temperature-triggered treatments indicated that cumulative oyster mortality at MB and SI was affected by Site and Depth with no other significant main effects or interactions (Table 6). The experimental oysters experienced higher mortalities at SI than at MB and had higher cumulative mortality when dropped to $10 \mathrm{~m}$ as opposed to $15 \mathrm{~m}$ (Fig. 8). 
Table 3. Pearson correlations between oyster instantaneous growth $\left(\% \mathrm{~d}^{-1}\right)$ and selected variables at $3 \mathrm{~m}$ at each study site (see Fig. 1 for abbreviations). p-values are in brackets; bold: $\mathrm{p}<0.05$. pHAB = potentially harmful algal bloom

\begin{tabular}{|lcccc|}
\hline Variable & MB & SI & TC & TI \\
\hline Date & $-0.364(0.376)$ & $-0.110(0.795)$ & $-\mathbf{0 . 7 0 9}(\mathbf{0 . 0 4 9 )}$ & $-0.667(0.071)$ \\
Daily average temperature $\left({ }^{\circ} \mathrm{C}\right)$ & $0.003(0.995)$ & $-0.081(0.849)$ & $-0.297(0.475)$ & $-0.172(0.683)$ \\
Diatom biomass $\left(\mathrm{mg} \mathrm{C} \mathrm{l}^{-1}\right)$ & $-0.241(0.565)$ & $0.413(0.309)$ & $-0.547(0.203)$ & $-0.147(0.729)$ \\
Dinoflagellate biomass $\left(\mathrm{mg} \mathrm{C} \mathrm{l}^{-1}\right)$ & $0.196(0.642)$ & $-0.099(0.817)$ & $\mathbf{0 . 7 9 7}(\mathbf{0 . 0 3 2})$ & $0.446(0.268)$ \\
pHAB biomass $\left(\mathrm{mg} \mathrm{C} \mathrm{l}^{-1}\right)$ & $-0.489(0.219)$ & $-0.369(0.369)$ & $-0.275(0.550)$ & $\mathbf{0 . 8 7 8 ( 0 . 0 0 4 )}$ \\
\% diatoms of total biomass & $-0.608(0.110)$ & $\mathbf{0 . 7 4 9 ( 0 . 0 3 3 )}$ & $-0.543(0.207)$ & $-0.335(0.417)$ \\
\% dinoflagellates of total biomass & $\mathbf{0 . 8 3 6 ( 0 . 0 1 0 )}$ & $0.097(0.819)$ & $0.684(0.090)$ & $0.119(0.779)$ \\
\% pHAB of total biomass & $-0.267(0.523)$ & $-0.329(0.427)$ & $-0.359(0.429)$ & $0.302(0.468)$ \\
Chlorophyll concentration $\left(\mathrm{mg} \mathrm{m}^{-3}\right)$ & $-0.735(0.265)$ & $0.441(0.274)$ & $0.651(0.349)$ & $0.810(0.071)$ \\
Secchi depth $(\mathrm{m})$ & $-0.267(0.523)$ & $-0.185(0.661)$ & $-0.773(0.125)$ & $-0.677(0.210)$ \\
Salinity & $-0.520(0.187)$ & $-0.251(0.548)$ & $-0.345(0.569)$ & $-0.606(0.279)$ \\
\hline
\end{tabular}

Table 4. Pearson correlations between oyster instantaneous mortality $\left(\% \mathrm{~d}^{-1}\right)$ and selected variables at $3 \mathrm{~m}$ at Metcalf Bay $(\mathrm{MB})$ and Sykes Island (SI). $\mathrm{p}$-values are in brackets; bold: $\mathrm{p}<0.05 . \mathrm{pHAB}=$ potentially harmful algal bloom

\begin{tabular}{|lcc|}
\hline Variable & MB & SI \\
\hline Date & $0.632(0.093)$ & $-0.451(0.262)$ \\
Daily average temperature $\left({ }^{\circ} \mathrm{C}\right)$ & $\mathbf{- 0 . 7 0 9 ( 0 . 0 4 9 )}$ & $\mathbf{0 . 7 3 5}(\mathbf{0 . 0 3 8})$ \\
Diatom biomass $\left({\left.\mathrm{mg} \mathrm{C} \mathrm{l}^{-1}\right)}^{\text {Dinoflagellate biomass }\left(\mathrm{mg} \mathrm{C}^{-1}\right)}\right.$ & $0.054(0.898)$ & $\mathbf{0 . 9 2 4}(\mathbf{0 . 0 0 1})$ \\
pHAB biomass $\left(\mathrm{mg} \mathrm{C}^{-1}\right)$ & $0.165(0.696)$ & $-0.242(0.564)$ \\
\% diatoms of total biomass & $0.076(0.857)$ & $\mathbf{0 . 7 0 7}(\mathbf{0 . 0 5 0})$ \\
$\%$ dinoflagellates of total biomass & $-0.358(0.327)$ & $0.645(0.084)$ \\
\% pHAB of total biomass & $-0.148(0.727)$ & $-0.598(0.117)$ \\
Chlorophyll concentration $\left(\mathrm{mg} \mathrm{m}^{-3}\right)$ & $-0.020(0.980)$ & $\mathbf{0 . 7 7 1}(\mathbf{0 . 0 2 5})$ \\
Secchi depth $(\mathrm{m})$ & $\mathbf{0 . 9 0 6}(\mathbf{0 . 0 0 2})$ & $-0.396(0.331)$ \\
Salinity & $0.628(0.096)$ & $-0.316(0.446)$ \\
\hline
\end{tabular}

\section{DISCUSSION}

Temperature, salinity, and chlorophyll

Seawater temperature and salinity at the 4 sites had typical profiles for estuaries around the Strait of Georgia during the summer and fall (Thomson 1981). The temperature at most of the sites reached a maximum close to $19^{\circ} \mathrm{C}$, which is the metabolic optimum for Pacific oysters (Bougrier et al. 1995). The exception was SI, which presented slightly higher temperatures during the summer. The sites presented a gradient of salinity regimes with $\mathrm{MB}$ on one end, with relatively high values throughout the water column due to strong tidal currents, TI and $\mathrm{TC}$ in an intermediate position, and SI

Table 5. Two-way ANOVAs on final oyster volume (ml) and cumulative oyster mortality $(\%)$ in the 3,10 , and $15 \mathrm{~m}$ fixed depth controls at study sites (see Fig. 1 for abbreviations) that share the same initial oyster size; bold: $\mathrm{p}<0.05 ; \mathrm{n}=3$

\begin{tabular}{|lcccc|}
\hline & df & MS & $F$ & $\mathrm{p}$ \\
\hline Oyster volume & & & & \\
MB and SI & & & & \\
$\quad$ Site & 1 & 420.494 & 57.304 & $<\mathbf{0 . 0 0 0 1}$ \\
Depth & 2 & 466.551 & 63.580 & $<\mathbf{0 . 0 0 0 1}$ \\
Site $\times$ Depth & 2 & 5.692 & 0.776 & 0.482 \\
Error & 12 & 7.338 & & \\
TC and TI & & & & \\
Site & 1 & 18.801 & 0.336 & 0.573 \\
Depth & 2 & 1216.208 & 21.737 & $\mathbf{0 . 0 0 0 1}$ \\
Site $\times$ Depth & 2 & 114.540 & 2.047 & 0.172 \\
Error & 12 & 55.950 & & \\
Oyster mortality & & & & \\
MB and SI & & & & \\
Site & 1 & 22865.793 & 503.918 & $<\mathbf{0 . 0 0 0 1}$ \\
Depth & 2 & 286.292 & 6.309 & $\mathbf{0 . 0 1 3}$ \\
Site $\times$ Depth & 2 & 141.397 & 3.116 & 0.081 \\
Error & 12 & 45.376 & & \\
\hline
\end{tabular}

with the lowest values and the largest difference between surface and deeper waters. The salinities measured during the present study were always at levels that are not likely to jeopardize oyster physiology (Bernard 1983), and salinity did not have significant correlations with instantaneous oyster growth or mortality at any of the study sites. Chlorophyll levels were within the values expected for inlets around the Strait of Georgia during the summer (Haigh et al. 1992, Masson \& Peña 2009).

\section{Phytoplankton and harmful algae}

\section{General phytoplankton}

The sites monitored during this study cover many of the marine environments present around the Strait of Georgia (Thomson 1981), being similar in oceanographic conditions, phytoplankton composition, and species succession to those studied by Haigh et al. 

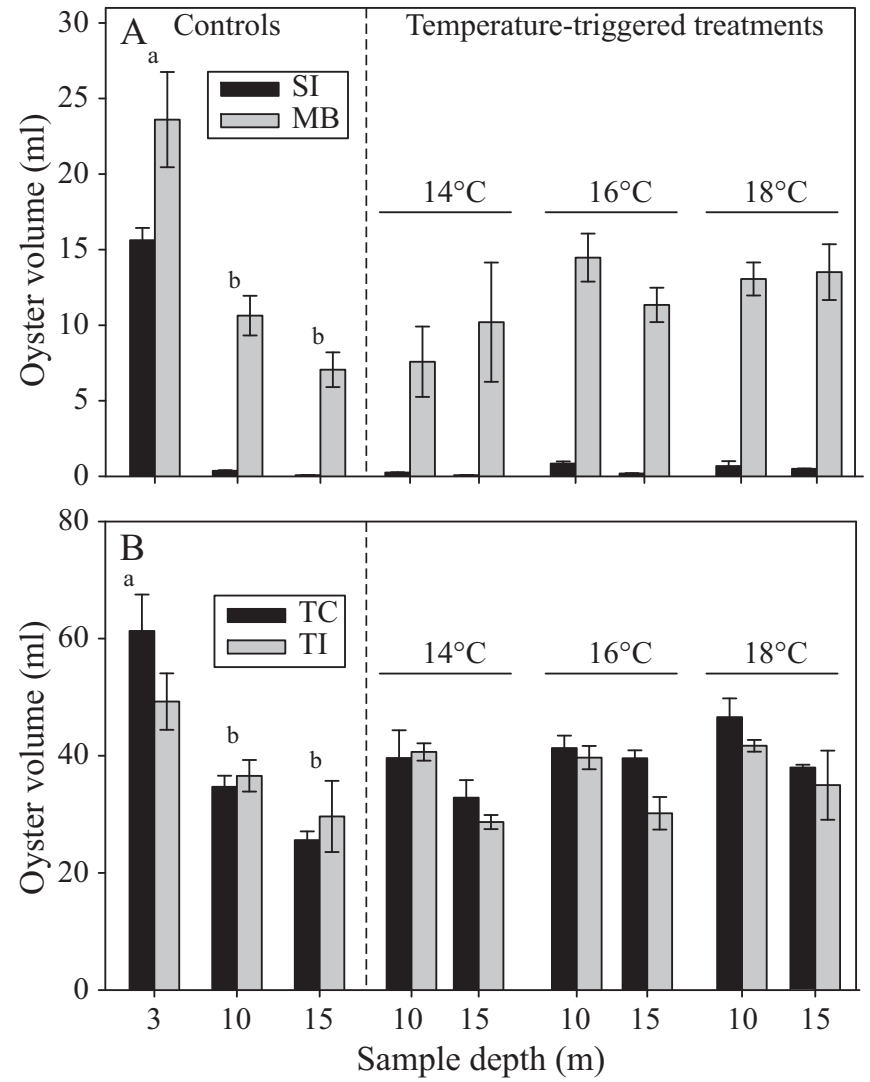

Fig. 7. Final oyster volume $(\mathrm{ml}$, mean $\pm \mathrm{SE}, \mathrm{n}=3)$ at $(\mathrm{A})$ Sykes Island (SI) and Metcalf Bay (MB), and (B) Thor's Cove (TC) and Trevenen Inlet (TI) for controls and for each treatment combination $\left(14,16\right.$, or $18^{\circ} \mathrm{C}$ temperature trigger and 10 or $15 \mathrm{~m}$ depth). Note scale difference between graphs. Different letters above bars indicate significantly different (Tukey's, $\mathrm{p}<0.05$ ) depths among sites

(1992): a diatom-dominated narrow channel with strong currents mediating seawater mixing (MB), a flagellatedominated and strongly stratified bay with important freshwater input (SI), and 2 intermediate (mid-channel) sites with an equal representation of the major taxonomic phytoplankton groups (TC and TI). The phytoplankton species succession also followed the normal general pattern for fjords located around the Strait of Georgia - a bloom of flagellates at the end of spring, followed by the onset of summer species and the fall diatom bloom (Harrison \& Yin 1998). Temperature and salinity determined the composition of the phytoplankton community.

Potentially harmful and toxic algae

Two bloom periods of pHABs were identified at the 4 study sites during the summer: Heterosigma akashiwo and Dictyocha speculum during June and July, and
Table 6. Three-way ANOVAs on final oyster volume (ml) and cumulative oyster mortality (\%) at sites (see Fig. 1 for abbreviations) that share same initial oyster size. TT: temperature trigger; bold: $\mathrm{p}<0.05 ; \mathrm{n}=3$

\begin{tabular}{|c|c|c|c|c|}
\hline & $\mathrm{df}$ & MS & $F$ & $\mathrm{p}$ \\
\hline \multicolumn{5}{|l|}{ Oyster volume } \\
\hline \multicolumn{5}{|l|}{ MB and SI } \\
\hline Site & 1 & 1314.616 & 191.947 & $<0.0001$ \\
\hline TT & 2 & 23.046 & 3.365 & 0.052 \\
\hline Depth & 1 & 1.786 & 0.261 & 0.614 \\
\hline Site $\times \mathrm{TT}$ & 2 & 16.632 & 2.428 & 0.110 \\
\hline Site $\times$ Depth & 1 & 0.041 & 0.006 & 0.939 \\
\hline TT $\times$ Depth & 2 & 5.862 & 0.856 & 0.438 \\
\hline Site $\times$ TT $\times$ Depth & 2 & 4.593 & 0.671 & 0.521 \\
\hline Error & 23 & 6.849 & & \\
\hline \multicolumn{5}{|l|}{$\mathrm{TC}$ and TI } \\
\hline Site & 1 & 121.474 & 4.882 & 0.037 \\
\hline $\mathrm{TT}$ & 2 & 71.236 & 2.863 & 0.077 \\
\hline Depth & 1 & 513.571 & 20.638 & $<0.0001$ \\
\hline Site $\times \mathrm{TT}$ & 2 & 11.768 & 0.473 & 0.629 \\
\hline Site $\times$ Depth & 1 & 30.836 & 1.239 & 0.277 \\
\hline TT $\times$ Depth & 2 & 10.567 & 0.425 & 0.659 \\
\hline Site $\times$ TT $\times$ Depth & 2 & 18.657 & 0.750 & 0.483 \\
\hline Error & 24 & 24.884 & & \\
\hline \multicolumn{5}{|l|}{ Oyster mortality } \\
\hline \multicolumn{5}{|l|}{ MB and SI } \\
\hline Site & 1 & 33619.454 & 484.972 & $<0.0001$ \\
\hline $\mathrm{TT}$ & 2 & 73.647 & 1.062 & 0.362 \\
\hline Depth & 1 & 722.333 & 10.420 & 0.004 \\
\hline Site $\times \mathrm{TT}$ & 2 & 146.323 & 2.111 & 0.144 \\
\hline Site $\times$ Depth & 1 & 52.688 & 0.760 & 0.392 \\
\hline TT $\times$ Depth & 2 & 74.246 & 1.071 & 0.359 \\
\hline Site $\times$ TT $\times$ Depth & 2 & 6.208 & 0.090 & 0.915 \\
\hline Error & 23 & 69.323 & & \\
\hline
\end{tabular}

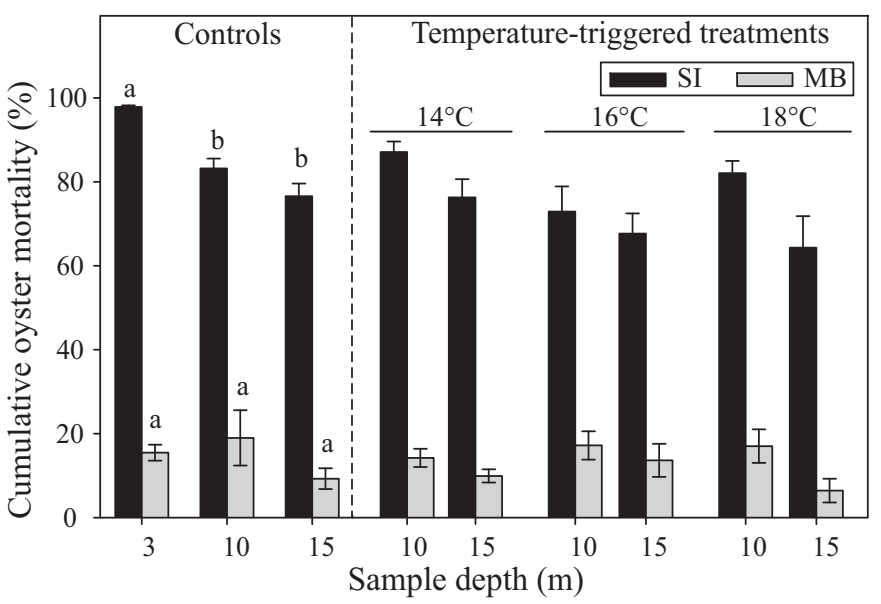

Fig. 8. Final cumulative oyster mortality (\%) at Sykes Island (SI) and Metcalf Bay (MB) in each temperature trigger and depth treatment combination and in controls (mean $\pm \mathrm{SE}, \mathrm{n}=$ 3). Different letters above bars indicate significantly different (Tukey's, p < 0.05) depths within sites 
Ceratium fusus and other dinoflagellates mainly during August, although with large differences in the intensity, persistence, and species composition among the sites. Strong and enduring summer stratification was associated with blooms at SI (Taylor et al. 1994, Taylor \& Harrison 2002). TC and TI had a small $H$. akashiwo bloom at the end of spring and a larger, mixed dinoflagellate bloom during late summer. Potentially harmful algae at MB were limited to transient periods of low abundance. A high abundance of pHABs can lead to lower oyster growth rates and survival (Gainey \& Shumway 1988, Alexander et al. 2006, King et al. 2006). During the present study, pHABs and oysters interacted differently at the 4 sites: pHABs were positively correlated with instant oyster mortalities at SI and with instantaneous growth rate at TI, suggesting that larger oysters (used at TC and TI) were not as susceptible to the blooms' harmful effects.

Heterosigma akashiwo was the most common and abundant potentially harmful algal species noted during this study, with the duration and intensity of its blooms being the most evident differences among sites in the phytoplankton community composition. This raphidophyte damages the digestive system in shellfish (Keppler et al. 2005), and pHAB biomass was indeed positively correlated with SI oyster mortality. Diatoms were also highly correlated with instant oyster mortality at SI, although they only represented $<6 \%$ of the total biomass at this site. The highest abundance of diatoms ( $22 \%$ of total biomass) occurred during the peak and decline of a bloom of $H$. akashiwo, thus, this correlation could be a coincidence. An increase in oyster mortalities was registered during the fall at $\mathrm{MB}$ after a bloom of the potentially harmful diatom Chaetoceros socialis (Lauder). This and other bloom-forming diatoms may cause clogging of the gills in shellfish (Landsberg 2002).

Toxic dinoflagellates and diatoms were more common when the water column was well mixed, such as at MB throughout the sample period, and towards the end of summer at TC and TI. These algae normally cause shellfish harvest closures, due to paralytic shellfish poison, in areas of the Strait of Georgia in August, as previously observed at TC and TI (Taylor \& Harrison 2002).

\section{Depth-manipulation experiment}

Fixed oyster-culture depth significantly affected the final volume and cumulative mortalities of oysters: individuals held at $3 \mathrm{~m}$ depth had larger final volumes than those in the 10 and $15 \mathrm{~m}$ depth control groups at all 4 sites, and oysters experienced significantly higher cumulative mortalities at $3 \mathrm{~m}$ than at 10 and $15 \mathrm{~m}$ at SI.
In addition, the test depth to which the temperaturetriggered treatments were dropped had a significant effect on final oyster volume at TC and TI and on cumulative mortalities at MB and SI. Those oysters that were dropped deeper had lower volumes and cumulative mortalities, but did not differ significantly from the fixed 10 and $15 \mathrm{~m}$ controls. These results agree with other studies in which higher growth and mortality rates were registered closer to the surface (Dégremont et al. 2005, Gagnaire et al. 2006, Ngo et al. 2006). For instance, Pacific oysters grown in Gosung Bay (Korea) at 0 to $2 \mathrm{~m}$ had a higher growth rate, gonadosomatic index, and fecundity than those held at a depth of 3 to $5 \mathrm{~m}$, most likely due to higher temperatures and/or an increased food supply (Ngo et al. 2006).

\section{Growth}

Several studies have investigated the growth and mortality of Pacific oysters across geographically and oceanographically distinct areas (e.g. Brown \& Hartwick 1988a,b, García-Esquivel et al. 2000, King et al. 2006). These studies and our results indicate that oysters grow better and have lower mortality rates at sites with higher diatom relative abundances, weaker haline and thermal stratification, and smaller temperature variations. The final oyster volumes in the current study were strongly site specific, confirming results from previous studies (e.g. Brown \& Hartwick 1988a). Despite identical initial oyster seed size, large final differences were found between $\mathrm{MB}$ and SI; oysters at $\mathrm{MB}$ grew to a final size $\sim 20$ times larger than at SI in most treatments (the exception was the $3 \mathrm{~m}$ control treatment where SI oysters attained $65 \%$ of the volume achieved by MB oysters). However, major differences in final oyster volume were not evident between TC and TI.

Phytoplankton is the main driving force for oyster growth (Ren \& Schiel 2008), and phytoplankton quality and quantity are strongly correlated with both oyster growth rates (Toro et al. 1999) and survival (Hyun et al. 2001, King et al. 2006). Similarly, the main variables significantly correlated with instantaneous oyster growth rate in the present study were components of the phytoplankton community. Diatoms are the preferred food for oysters (Dupuy et al. 2000, Marshall et al. 2010) and were positively correlated with oyster instantaneous growth at SI despite being scarce at this site. In contrast, dinoflagellates were correlated with instantaneous oyster growth at $\mathrm{MB}$ and $\mathrm{TC}$, although the phytoplankton at MB was dominated by diatoms. Dinoflagellates have a higher content of carbon and protein per unit volume than diatoms, which could make them trophically preferable for oysters in a 
diatom-rich environment (Menden-Deuer \& Lessard 2000). The lack of significant correlations of chlorophyll concentration and Secchi depth with instantaneous oyster growth rates indicates that the phytoplankton composition, rather than the total amount of phytoplankton biomass in the water, is the main factor in fuelling oyster growth.

Current speed is an important factor for oyster performance, mainly due to its effects on food acquisition (Lenihan 1999). All sites were subjected to tidal and wind-driven currents and, although no direct measurements of flow speed were made at the sites, no large differences in flow were observed during sampling. Our data did not differ significantly between protected (TI) and exposed (TC) sites, corroborating the results of a previous study which used nearby locations in Desolation Sound (Wiley \& Zahradnik 1981).

The initial size of the oysters in the present study was also an important factor for their growth rate, as oysters grow rapidly during their first year and more slowly thereafter (Sumner 1981). Our results reflect this growth pattern, as the larger seed oysters (at TC and TI) reached $\sim 8$ times their initial size while the smaller seed (at MB and SI) grew up to 200 times their starting volume, similar to results obtained by Gangnery et al. (2003).

\section{Mortality}

Large differences in cumulative oyster mortality were found between MB and SI as oysters at the latter site had 3 to 4 times lower survival than those at the former site. Cumulative oyster mortality observed at MB during the present study was similar or lower than the 25 to $30 \%$ reported as being normal for Pacific oysters during their first year in culture (García-Esquivel et al. 2000, Burge et al. 2007). Instant oyster mortality rates varied at MB throughout the summer, similar to results reported by Soletchnik et al. (2006), but increased towards the fall, as was also observed by King et al. (2006). The increase we recorded in the fall was possibly linked to a bloom of Chaetoceros socialis. Conversely, SI had high oyster mortality rates at the start of the study, as was also seen in $7 \mathrm{~mm}$ long oysters by Dégremont et al. (2005), levelling off later in the summer. Soletchnik et al. (2006) also described a peak in summer mortalities during June, which was associated with physiological stress due to accelerated growth. At SI, instantaneous oyster mortality was positively correlated with temperature, pHAB biomass, diatom biomass, and chlorophyll concentration, while at MB it was negatively correlated with temperature and positively correlated with water transparency. Although seawater temperatures at these sites rarely reached levels that could cause stress in the oysters, high temperature periods have been identified as one of the main factors in summer mortality events (Cardwell et al. 1979, Brown \& Hartwick 1988a,b, Burge et al. 2007). In the present study, the oyster mortality rate at SI was higher during the warmer, more stratified periods and near the water surface. At MB, the correlation with temperature was negative, as the highest mortality rates occurred during the fall.

Pacific oysters acquire adult capabilities for particle processing and selectivity (being able to reject large, spiny and some toxic algal species; Cassis \& Taylor 2006) at a shell length of $\sim 2.4 \mathrm{~cm}$ (Cannuel \& Beninger 2007). The oysters at TC and TI were at or above this critical size at the start of our study, whereas the seed at MB and SI only reached it during late July. The reduced particle selectivity of smaller oysters and the high abundance of harmful algae at SI could be major causes of the large oyster mortality rate at this site. In contrast, oyster growth was fast and mortality rates were negligible during the early summer at TC and TI despite abundant pHABs. Chlorophyll concentration was also positively correlated with instantaneous oyster mortality at SI, probably because abundant pHABs produced a similar increase in the total chlorophyll concentration. Transparency (Secchi depth) was correlated with instant mortality at MB throughout the study period. Nonetheless, the elevated mortalities observed during the fall might have been partially caused by a bloom of Chaetoceros socialis, which could clog the gills of shellfish due to the large size of their colonies.

High temperature and low salinity were the factors that best separated high (MB) and low ( $\mathrm{Si}, \mathrm{TC}, \mathrm{TI})$ mortality sites (Fig. 9). Salinity was not significantly correlated with instantaneous mortality at either $\mathrm{MB}$ or $\mathrm{SI}_{\text {; }}$ nevertheless, it may have acted as the initiator in a cascade of events that led to increased oyster mortalities at SI. High freshwater input during the spring reduced the surface salinity, inducing stratification in the water column. This surface water was then heated by the sun, and the strong stratification probably prevented heat transfer to deeper waters. These high-temperature, lowsalinity, and strongly stratified waters have been described as ideal environments for halotolerant motile algae but inadequate for diatoms (Bearon et al. 2006). SI was characterized by large blooms dominated by Heterosigma akashiwo during June and Ceratium fusus during August, while diatoms accounted for only $6 \%$ of the total phytoplankton biomass. The oysters at this site were then faced with periods of high temperatures (up to $26.7^{\circ} \mathrm{C}$ ), HABs, and lack of nutritive particles overlapping in quick succession. Stress, starvation, and malnutrition caused by pHABs during the summer could result in oysters with a reduced immune response (Galimany et al. 2008). This could then lead 
to a higher susceptibility to infection by parasites and opportunistic diseases (Friedman et al. 1991, Chu et al. 2002, Burge et al. 2007) and thus increased mortalities in the stressed oysters. The particularly extended period of low salinity and strong stratification that was conducive to large blooms of $H$. akashiwo and $C$. fusus seen at SI was not observed at any other site, except for a short period at TC and TI. The low stratification and strong tidal mixing prevalent at $\mathrm{MB}$ were favorable to diatoms. TC and TI presented intermediate values of salinity and temperature, although closer to $\mathrm{MB}$ than SI (Fig. 9); in addition, their phytoplankton was an average of the SI and MB extremes.

\section{CONCLUSIONS}

MB had the best oyster-growing conditions, having a well-mixed water column, high salinity, low temperature, and dominance by preferred diatoms. Undesirable conditions at the SI site-strong and enduring stratification, a long period of low salinity, high temperature, and pHABs which resulted in large mortality rates and reduced growth - should be avoided for the culture of small oyster juveniles. Site selection is critical for culture of seed oysters throughout the Strait of Georgia.

Significantly higher growth and mortality rates were seen in oysters held closer to the surface $(3 \mathrm{~m})$ than in those cultured deeper (10 or $15 \mathrm{~m}$ ). The $3 \mathrm{~m}$ fixed culture depth was seen as the optimum, due to the larger final oyster volumes obtained, despite the higher mortality rates registered at this depth. Depth manipulation, based on temperature as the trigger for oyster movement, failed to produce significantly better

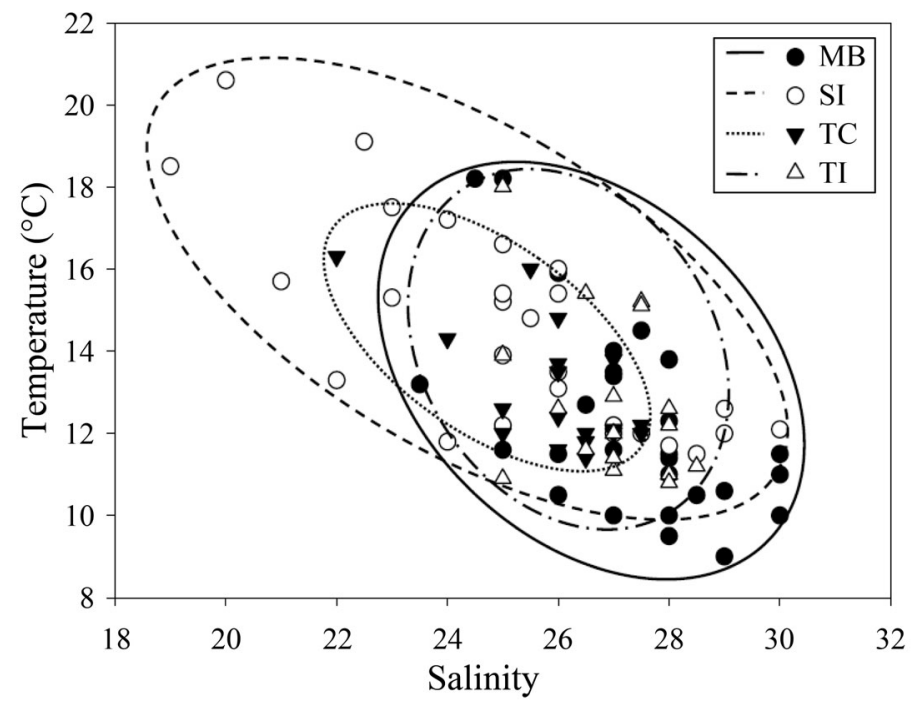

Fig. 9. Seawater temperature $\left({ }^{\circ} \mathrm{C}\right)$ and salinity at each study site, measured every $2 \mathrm{wk}$ (see Fig. 1 for abbreviations) growth or survival than the fixed controls at similar depths. Depth manipulation of oysters remains as a potential management option to reduce summer mortalities, but needs to be researched further as the present study showed that temperature was inadequate as a sole trigger for significantly reducing oyster mortality rate. Potential trigger variables for further study would include various phytoplankton taxonomic groups. Oyster culture sites should be studied in terms of temperature and salinity regimes as well as phytoplankton composition and species succession, to optimize the balance between oyster growth and mortality.

Acknowledgements. Funding and in-kind support for this research were provided by the Aquaculture Collaborative Research and Development Program of Fisheries and Oceans Canada, the British Columbia Shellfish Growers Association (BCSGA), the University of British Columbia, Mac's Oysters Ltd. (G. McLellan), and Taylor Shellfish Farms (C. Day). We thank L. Moccia, J. Foster, J. Clark, G. Clark, and S. Pickens for assistance with field sampling, and D. McCallum (BCSGA) for his help in coordinating this project.

\section{LITERATURE CITED}

Alexander J, Meritt D, Pareletti A, Alexander S, Stoecker D, Glibert P (2006) Effects of harmful algae on oyster growth. J Shellfish Res 25:706-707

Baldwin BS, Newell RIE (1995) Feeding rate responses of oyster larvae (Crassostrea virginica) to seston quantity and composition. J Exp Mar Biol Ecol 189:77-91

Bearon RN, Gruenbaum D, Cattolico RA (2006) Effects of salinity structure on swimming behaviour and harmful algal bloom formation in Heterosigma akashiwo, a toxic raphidophyte. Mar Ecol Prog Ser 306:153-163

Bernard FR (1983) Physiology and the mariculture of some northeastern Pacific bivalve molluscs. Publ Spec Can Sci Halieut Aquat 63:1-24

Bougrier S, Geairon P, Deslous-Paoli JM, Bacher C, Jonquieres G (1995) Allometric relationships and effects of temperature on clearance and oxygen consumption rates of Crassostrea gigas (Thunberg). Aquaculture 134:143-154

> Brown JR, Hartwick EB (1988a) Influences of temperature, salinity and available food upon suspended culture of the Pacific oyster, Crassostrea gigas. I. Absolute and allometric growth. Aquaculture 70:231-251

Brown JR, Hartwick EB (1988b) Influences of temperature, salinity and available food upon suspended culture of the Pacific oyster, Crassostrea gigas. II. Condition index and survival. Aquaculture 70:253-267

> Burge CA, Judah LR, Conquest LL, Griffin FJ and others (2007) Summer seed mortality of the Pacific oyster, Crassostrea gigas Thunberg grown in Tomales Bay, California, USA: the influence of oyster stock, planting time, pathogens, and environmental stressors. J Shellfish Res 26:163-172

Cannuel R, Beninger PR (2007) Acquisition of particle processing capability in juvenile oyster Crassostrea gigas: ontogeny of gill mucocytes. Mar Biol 151:897-905

Cardwell RD, Olsen S, Carr MI, Sanborn EW (1979) Causes of oyster larvae mortality in south Puget Sound. NOAA Tech Memo no. ERL MESA-39. Washington Department of Fisheries, Salmon Research and Development, Brinnan, WA

Cassis D, Taylor FJR (2006) Rapid responses of juvenile 
oysters exposed to potentially harmful phytoplankton. Extended abstract, 5th Int Conf Molluscan Shellfish Safety, Galway, Ireland, 14-18 June 2004, Marine Institute, Galway, p 65-70

Cheney DP, Elston RA, MacDonald BF, Cherr GN, Hamdoun AM, Jacobsen JL (2000) An update on the ongoing oyster summer mortality study: mortality of the Pacific oyster, Crassostrea gigas: health screening, environmental links and management options. J Shellfish Res 19:685 (Abstract)

Chu FLE, Volety AK, Hale RC, Huang Y (2002) Cellular responses and disease expression in oysters (Crassostrea virginica) exposed to suspended field-contaminated sediments. Mar Environ Res 53:17-35

> Dégremont L, Bédier E, Soletchnik P, Ropert M and others (2005) Relative importance of family, site, and field placement timing on survival, growth and yield of hatchery-produced Pacific oyster spat (Crassostrea gigas). Aquaculture 249:213-229

Dupuy C, Vaquer A, Lam-Höai T, Rougier C and others (2000) Feeding rate of the oyster Crassostrea gigas in a natural planktonic community of the Mediterranean Thau Lagoon. Mar Ecol Prog Ser 205:171-184

FAO (Food and Agriculture Organization) (2006) State of the world aquaculture. FAO Fish Tech Pap 500. FAO, Rome

Friedman CS, Beattie JH, Elston RA, Hedrick RP (1991) Investigation of the relationship between the presence of a gram-positive bacterial infection and summer mortality of the Pacific oyster, Crassostrea gigas Thunberg. Aquaculture 94:1-15

Gagnaire B, Soletchnik P, Madec P, Geairon P, Le Moine O, Renault T (2006) Diploid and triploid oysters, Crassostrea gigas (Thunberg), reared at two heights above sediment in Marennes-Oleron basin, France: difference in mortality, sexual maturation and hemocyte parameters. Aquaculture 254:606-616

Gainey L, Shumway SE (1988) A compendium of the responses of bivalve molluscs to toxic dinoflagellates. J Shellfish Res 7:623-628

> Galimany E, Sunila I, Hégaret H, Ramón M, Wikfors GH (2008) Experimental exposure of the blue mussel (Mytilus edulis, L.) to the toxic dinoflagellate Alexandrium fundyense: histopathology, immune responses, and recovery. Harmful Algae 7:702-711

Gangnery A, Chabirand JM, Lagarde F, Le Gall P, Oheix J, Bacher C, Buestel D (2003) Growth model of the Pacific oyster, Crassostrea gigas, cultured in Thau Lagoon (Méditerranée, France). Aquaculture 215:267-290

García-Esquivel Z, González-Gómez MA, Gómez-Togo DL, Galindo-Bect MS, Hernández-Ayón M (2000) Microgeographic differences in growth, mortality, and biochemical composition of cultured Pacific oysters (Crassostrea gigas) from San Quintin Bay, Mexico. J Shellfish Res 19:789-797

Gill AE (1982) Atmosphere-ocean dynamics. Academic Press, San Diego, CA

> Haigh R, Taylor FJR, Sutherland TF (1992) Phytoplankton ecology of Sechelt Inlet, a fjord system on the British Columbia coast. I. General features of the nano- and microplankton. Mar Ecol Prog Ser 89:117-134

Harrison PJ, Yin K (1998) Ecosystem delineation in the Strait of Georgia basin based on nutrients, chlorophyll, phytoplankton species and primary productivity. Can Tech Rep Fish Aquat Sci 2247:124-135

Hasle GR (1978) Using the inverted microscope. In: Sournia A (ed) Phytoplankton manual. Monographs on oceanographic methodology 6. UNESCO, New York, NY, p 161-178

> Hyun KH, Pang IC, Klinck JM, Choi KS and others (2001) The effect of food composition on Pacific oyster Crassostrea gigas (Thunberg) growth in Korea, a modeling study. Aquaculture 199:41-62

Keppler CJ, Hoguet J, Smith K, Ringwood AH, Lewitus AJ (2005) Sublethal effects of the toxic alga Heterosigma akashiwo on the southeastern oyster (Crassostrea virginica). Harmful Algae 4:275-285

King JW, Malham SK, Skov MW, Cotter E, Latchford JW, Culloty SC, Beaumont AR (2006) Growth of Crassostrea gigas spat and juveniles under differing environmental conditions at two sites in Wales. Aquat Living Resour 19:289-297

> Landsberg JH (2002) The effect of harmful algal blooms on aquatic organisms. Rev Fish Sci 10:113-390

Lenihan HS (1999) Physical-biological coupling on oyster reefs: how habitat structure influences individual performance. Ecol Monogr 69:251-275

> Marshall R, McKinley S, Pearce CM (2010) Effects of nutrition on larval growth and survival in bivalves. Rev Aquacult 2: $33-55$

Masson D, Cummins PF (2007) Temperature trends and interannual variability in the Strait of Georgia, British Columbia. Contin Shelf Res 27:634-649

> Masson D, Peña A (2009) Chlorophyll distribution in a temperate estuary, the Strait of Georgia and Juan de Fuca Strait. Estuar Coast Shelf Sci 82:19-28

- Menden-Deuer S, Lessard EJ (2000) Carbon to volume relationships for dinoflagellates, diatoms, and other protist plankton. Limnol Oceanogr 45:569-579

Moal J, Lambert MJ, Pouvreau S, Le Moullac G, Samain JF (2007) Temperature as a risk factor in oyster summer mortality. In: Samain JF, McCombie H (eds) Summer mortality of the Pacific oyster Crassostrea gigas: the Morest Project. Editions Quae, Versailles, p 289-306

Montagnes DJS, Franklin DJ (2001) Effect of temperature on diatom volume, growth rate, and carbon and nitrogen content: reconsidering some paradigms. Limnol Oceanogr 46: 2008-2018

Ngo TTT, Kang SG, Kang DH, Sorgeloos P, Choi KS (2006) Effect of culture depth on the proximate composition and reproduction of the Pacific oyster, Crassostrea gigas from Gosung Bay, Korea. Aquaculture 253:712-720

Pauley GP, Van der Raay B, Troutt D (1988) Species profile, life histories and environmental requirements of coastal fishes and invertebrates (Pacific Northwest). Pacific oyster. US Fish and Wildlife Service, Biol Rep 82. US Army Corps of Engineers, TR EL-82.4

Quayle DB (1988) Pacific oyster culture in British Columbia. Can Bull Fish Aquat Sci 218

Ren JS, Schiel DR (2008) A dynamic energy budget model, parameterisation and application to the Pacific oyster Crassostrea gigas in New Zealand waters. J Exp Mar Biol Ecol 361:42-48

Samain JF, McCombie H (eds) (2007) Summer mortality of the Pacific oyster Crassostrea gigas: the Morest Project. Editions Quae, Versailles

Shumway SE, Barter J, Sherman-Caswell S (1990) Auditing the impact of toxic algal blooms on oysters. Environ Auditor 2: 41-56

Soletchnik P, Faury N, Goulletquer P (2006) Seasonal changes in carbohydrate metabolism and its relationship with summer mortality of Pacific oyster Crassostrea gigas (Thunberg) in Marennes-Oleron Bay (France). Aquaculture 252:328-338

> Strathmann RR (1967) Estimating the organic carbon content of phytoplankton from cell volume or plasma volume. Limnol Oceanogr 12:411-418

Sumner CE (1981) Growth of Pacific oysters, Crassostrea gigas Thunberg, cultivated in Tasmania. II. Subtidal culture. 
Aust J Mar Freshwater Res 32:411-416

Taylor FJR, Harrison PJ (2002) Harmful algal blooms in western Canadian coastal waters. In: Taylor FJR, Trainer VM (eds) Harmful algal blooms in the PICES region of the north Pacific. PICES Sci Rep 23:77-88

Taylor FJR, Haigh R, Sutherland TF (1994) Phytoplankton ecology of Sechelt Inlet, a fjord system on the British Columbia coast. II. Potentially harmful species. Mar Ecol Prog Ser 103:151-164

Thomson RE (1981) Oceanography of the British Columbia coast. Can Spec Publ Fish Aquat Sci 56

Toro JE, Paredes PI, Villagra DJ, Senn CM (1999) Seasonal

Editorial responsibility: Tim Dempster,

Trondheim, Norway variation in the phytoplanktonic community and environmental variables during a 2-year period and oyster growth at 2 mariculture sites, southern Chile. PSZN I: Mar Ecol 20:63-89

- Wildish D, Lassus P, Martin J, Saulnier A, Bardouil M (1998) Effect of the PSP-causing dinoflagellate, Alexandrium sp. on the initial feeding response of Crassostrea gigas. Aquat Living Resour 11:35-43

> Wiley K, Zahradnik J (1981) Performance evaluation of a suspension tray system for the culture of Pacific oysters, Crassostrea gigas, in Trevenen Bay, British Columbia. J World Maricult Soc 12:64-75

Submitted: November 26, 2010; Accepted: May 14, 2011

Proofs received from author(s): June 27, 2011 